\title{
Strategic Management of Innovation Towards Sustainable Development of Brazilian Electronics Industry
}

\author{
Marco Antonio Silveira
}

\begin{abstract}
This paper presents and discusses the baselines of a nationwide project whose objective is to support the economic, social and environmental sustainability of Brazilian electronics industry. This project encompasses a complex and innovative articulation of a large number of multidimensional variables and includes some innovative solutions. It foresees the execution of a pilot project with the participation of nine companies producers of electro medical equipment. Its implementation occurs by coordinating innovation of products and processes with the integrated management of the marketing mix of products, by means of the integration of the company's management systems. It is presented the theoretical and methodological foundations of this pilot project, its structure and organization, and the main results obtained so far.
\end{abstract}

Keywords: organizational sustainability; innovation management; intellectual capital; cleaner production.

DTSD-G.A.I.A./ Support Group for Innovation and Learning in Organizations, CTI-MCTI/Center for Information Technology Renato Archer, Rod. Dom Pedro I km 143 - Campinas - Brazil - I3069-90I.Phone: (55I9)37466083. E-mail: marco.silveira@cti.gov.br 


\section{Introduction}

After a period of decline, notably in the 90's, Brazil is experiencing a process of resumption of industrial growth that, despite strong fluctuations, has been a positive one since the year 2000.

Amongst sectors considered a priority for the resumption of industrial development in the country, there are those that comprise the electro-electronic industry, such as electronic components, informatics, telecommunications, electronic consumer and capital goods. These sectors have a crucial role in the economic system, since they generate a great number of products and are present, even indirectly, in several other sectors (Oliveira e Silveira, 2009).

For the same reasons, the electro-electronic industry has significant importance in Brazil's productive chains. Their technology advancement rapidly irradiated to several other sectors, generating an intense multiplying effect over the economy as a whole (ABINEE, 2009). This industry, nowadays dominated by large multinational companies, has within itself quite dynamic sectors, producers of a significant portion of the world's wealth and innovations, innovations that occur with regularity and in an accelerated manner. This allows the segment to be viewed as a segment of high revolutionary potential, creator of new paradigms both in terms of products and processes, as well as in terms of new forms of industrial organization.

\section{The environmental imperative and the electro-electronic industry}

Besides the inherent challenges of constantly and rapidly shifting environments, the current moment imposes other challenges to companies, that result of the complexity and high competition levels required in an even more globalized market.

The necessity of environmental compliance is one of these challenges that have acquired a great deal of importance. In Brazil, this is expressed in the recently launched National Policy on Solid Wastes (NPSW). In international markets, due to its economic relevance and environmental impacts, the electro-electronic industry has gained special attention: since 2006 the directives Waste of Electro-Electronic Equipments (WEEE) and the Restriction of Hazard Substances (RoHS) are in force in the European Community (EC). These directives are fully or partially being adopted in several other countries, such as China, Japan and the United States.

The WEEE directive deals with the final disposal of used electro-electronic equipments, defining requirements both for reduction of quantities of waste and the treatment of the generated waste. Additionally, the RoHS directive formally makes the manufacturer liable in case their products are composed of harmful substances (Lead, Mercury, Cadmium, Hexavalent chromium, Polybrominated biphenyls, Polybrominated diphenyl) in quantities over a predetermined rate, considering all the steps of the productive chain, since the raw materials utilized by suppliers to the client's use of the final product.

\section{Sustainability of the electro-electronic industry: The ABIMO Pilot Project proposal}

The ABIMO Pilot Project was formulated to face the various challenges mentioned above, challenges that are posed for the Brazilian electro-electronic industry, specially is small and medium sized companies; its fundamentals and the preliminary results are presented in the next sections of the present paper.

The proposal to support the electro-electronic companies was outlined based on two principles: socio-economic development with environmental balance, and integration of available intellectual capital leading to the gradual development of a favorable organizational ecosystem.

The first principle considers that companies should comply with the best environmental practices without losing the viability of their business or further interests of the society. Its concern, therefore, is the industry's sustainable development, integrating effectively the environmental dimension to the economic and social dimensions.

The second principle of this proposal is the coordination of the acting agents in the target ecosystem - companies, universities and research institutions (ERI), governmental entities, promoting institutions and regulatory organizations - with emphasis on the integrated management of the intellectual capital present in these organizations.

Given the size and complexity of the electro-electronic industry, the proposal of the ABIMO Pilot Project predicts the possibility of gradual development of actions, through progressive spillover of its results to successively broader organizational levels: starting with a pilot project involving a few companies of a specific sector, therefore expanding to the sector as a whole, and further in the mid and long term to other sectors of the electro-electronic industry.

\section{Pilot project in the electromedic equipment sector}

Commencing the attack of complex challenges through a pilot project allows one to deal with a smaller number of agents and variables. This facilitates the validation of proper methodologies to the reality of the country and to repli- 
cable them in other sectors and the identification of the effective competencies required to deal with the challenges posed. Through this approach, it is possible to create the systemic conditions that may favor the sustainability and the international insertion of the companies of interest.

Despite the high market concentration amongst the large multinational companies that compose the electro-electronic industry, there is a large number of small and medium sized companies that act in this industry, developing and marketing innovative technologies. Examples can be found on the software sector (Gouveia, 2004) and on the electromedic equipment (E.E.) sector.The E.E. sector in Brazil faces the challenges pointed out in this text in a specially intense way, being that it is composed by companies that are in their majority small to medium sized companies, exporters and technology-intensive.

Due to these features, it has been decided that the pilot project would be realized with E.E. manufacturing companies, decision totally supported by the Brazilian Industrial Association of Medical, Dental, Hospital and Laboratorial Equipment Articles (ABIMO), a producers association that congregates over $80 \%$ of the Brazilian companies of the sector. Since the purpose of the proposal is to contribute to the gradual development of favorable systemic conditions to the sustainability of the electro-electronic industry, the associated problem was defined as: "How to articulate the multiple agents that act in the ecosystem of the Brazilian E.E. sector, aiming towards the sustainable development of their companies through compliance to RoHS/WEEE/NPSW and promotion of their competitiveness in the national and international markets?".

The subsequent sections present the details concerning the pilot project with companies of the E.E. sector, details the theoretical and methodological fundamentals of the project, showing the project structure and the main results achieved in the period that covers november 2009 to april 2011.

\section{Theoretical fundamentals}

\section{Challenges towards organizational sustainability}

Throughout the last decades, several authors have been alerting to the damages caused by companies' actions on the environment. Aktouf (199I) pounders about the unsustainable characteristic of the current industrial model, alerting that "short term profit means long term destruction". Morgan (2006) affirms that "our companies are killing us, adulterating food, polluting the environment, and subjecting people to insalubrious conditions [...]".
Concerning these aggressions to the environment, the environmentalists introduced in the 80's the concept of sustainability, understood as addressing current necessities without compromising the necessities of future generations. In the 90's, Elkington (1999) proposed a broader scope to the idea of sustainability, expanding this concept towards the Triple Bottom Line (TBL) approach, or the "tripod of sustainability".

The TBL approach towards sustainability applied in the scope of organizations brings back the principles subjacent to excellence management, as it introduces the necessity to think about organizations in a holistic, balanced and responsible manner.That is so because organizational sustainability presumes balance in the treatment of interest and necessities of all the stakeholders of the organization: clients, owners, suppliers, employees and society.

Therefore, management aiming towards sustainability implicates in dealing with multiple variables connected to diverse tangible and intangible factors present in organizational systems. These factors are of a human, technological and organizational nature, therefore requiring an integrated management that articulates a wide range of resources and competencies (internal and external) in different areas of knowledge, amongst other components that constitute the intellectual capital of the institutions of the organizational system in focus.

\section{Intellectual capital as an instrument of organizational sustainability}

The availability of an adequate set of resources and competencies are not enough to assure that an organizational system will be effectively sustainable: it must be conveniently articulated and integrated in a way to create the necessary conditions to produce the expected results in the economic, social and environmental dimensions.

According to the neoclassical approach, organizational resources are restricted to capital, labor and land. However, as a consequence of the evolving dynamics of current times, the Resource Based approach includes among the organizational resources the "tangible and intangible assets that a firm has at its disposal and that allows it to produce in a more efficient or effective manner" (Sveiby, 1997). The set of intangible resources are referred to by various authors as Intellectual Capital, understood as those resources that do not possess physical existence, however represent value to a company (Edvisson e Malone, 1997), including the human intellectual capacity, and other intangible assets, such as brands and patents. 
Sveiby identifies three set of factors that compose intellectual capital: human capital, representing the knowledge and competencies of the company's collaborators; structural capital, involving softwares and managerial systems, and also the other organizational assets that may be related in the category of "intellectual property" (brands, patents, and others); and relational capital, corresponding to the knowledge generated through relationships with other organizations, such as clients and suppliers.

The emphasis given to intellectual capital in the ABIMO Pilot Project is based, therefore, on three sets of reasons:

a. The first, based on economic considerations (since intellectual capital is an economic asset), derives from the limitations of financial investments in Brazil, when compared to other competing nations, such as China and South Korea; b. The second, of a technological nature, derives from the evolving dynamics inherent to the electro-electronic industry, that requires constant innovations;

c. The third, of a systemic nature, derives from the necessity of new industrial models that effectively promote the sustainable development of a society, coherently with the TBL approach; the intellectual capital facilitates the integration of demands of the various stakeholders, since processes concerning knowledge rely heavily on the human factor.

\section{Strategies based on Innovation and Environmental Regulations}

In the 60's, when management was oriented towards individual functions, the need for an holistic approach to company management was identified and articulated on the concept of strategy (Montgomery and Porter, 1991). Since then, the importance of a strategic focus has grown in direct proportion to the increased level of competitiveness and rhythm of transformations in the business environment.

The sustaining of superior results is related, according to Day and Rebstein (2004), to an organization's capacity to develop sustainable competitive advantages. To do so, the organization has three great sets of strategies; overall costs leadership, leadership by product differentiation and exploration of niche markets (Porter, 1998). Strategies based on differentiation consider innovation an important instrument, what has been demonstrated by several authors since Schumpeter brought to light the idea of innovation as "creative destruction"; the following citation regards this matter: "Whilst competitive advantage can come from size, or possession of assets, etc. the pattern is increasingly coming to favor those organizations which can mobilize knowledge and technological skills and experience to create novelty in their offerings (product/service) and the ways in which they cre- ate and deliver those offerings." (Tidd, Bessant and Pavitt, 1997:5).

It is interesting to notice that environmental regulations, once inducing companies to reformulate their strategies towards the generation of new products, processes and services, generates technologic and organizational innovations with environmental, economic and social benefits that create competitive advantages, and consequently can enhance the company's market share.

“...many companies that are compliant to environmental legislation have developed technology innovations through seizing opportunities aroused during the re-engineering of products, processes and traditional operating methods; such innovations resulted in an enhancement of company competitiveness." (Reydon et alli, 2007)

A company can take advantage of these windows of opportunity through planning your marketing mix, which includes four groups of variables, known as the "four Ps": product, price, place and promotion. There are various marketing tools associated with each of these four groups, which may be used depending on the purpose of each strategic organization (Kotler and Armstrong, 2004).

\section{Organizations as a network of processes: Integrated management of organizational changes}

A system consists of several parts, generally referred to as components. There is a consensus in the literature about management systems that processes are the main components in an organization. This approach is not new (see Schoderbek et alli, 1980, Kast and Rosenzweg, 1985 and Kirby, (991), and has been explored more recently by various authors, for instance, Gonçalves (2000).

The various management systems standards (ISO 900I, ISO I 400 I, and others), released from the beginning of the last decade on, emphasized this form of conceiving organizations. This vision was explored deeply by Silveira (1999), showing the various advantages associated to this form of visualizing organizations and proposing associated methods towards diagnosing, planning and conducting changes in organizational systems.

The concept of process is multidimensional, as it integrates tangible assets, such as materials, equipments and facilities, and intangible assets, like those associated to intellectual capital; therefore it is a concept that includes the human and technologic dimensions. To conceive an organization as being built by a network of processes facilitates the integrated management of the several factors of interest, be it one company (see Silveira, 1999) or a network formed by several organizations (see Silveira, 2004). 


\section{The Design of the pilot project proposal}

It has been mentioned above that manufacturing company's E.E. face in an especially strong manner challenges imposed by current markets. In order to further comprehend this situation, various actions were accomplished during January and June of 2010, involving the research of available data about the E.E. sector, deep evaluation of some companies in the sector and the discussion of the preliminary results. A synthesis of the three steps of the pilot project structuring is presented below.

\section{Studies on the E.E. sector}

Initially a research on the Brazilian E.E. sector was conducted, utilizing secondary data obtained from reliable institutions and current academic work, looking to identify the profile of the companies that constitute the sector, and furthermore, to accomplish a preliminary survey on the technologies characteristics and the main challenges faced by the sector. Given the strategic importance to the country, the E.E. sector has been prioritized on studies published by several government agencies, like the Brazilian Agency of Industrial Development $(A B D I)$ and the National Bank of Economic and Social Development (BNDES). Several papers (ABDI, 2008, Pieroni et alli, 2010, and others) identify the following main characteristics of the E.E. sector: $a$. it is a sector that manufactures highly reliable and technology intensive products; b. it is an intensive exporting sector (15\% of the sector's income comes from exports), composed by a $93 \%$ of companies of national capital; c. $75 \%$ of the companies are small or middle sized, with growing income levels (200\% growth between 2003 and 2007).

With these preliminary data in hand, during January to March 2010 an exploratory research was conducted with nine companies associated to ABIMO that voluntarily participated on the project. In order to collect the information of interest, a semi-structured survey was conducted, contemplating the strategies designed for the business, products, productive processes, suppliers, logistic information, human resources and Research, Development and Innovation practices (RD\&I.). The nine companies have their productive plants located in the state of São Paulo, the more industrialized State of Brazil. The manufactured products are very diverse: electronic surgical scalpel (two companies), lung ventilators (two companies), incubators, surgical tables, esthetic equipment, infusion pumps and inhalers.

An action plan, based on the results of the survey, has been proposed to be implanted in this set of companies. In order to validate these proposals, three discussion panels were conducted involving approximately two hundred professionals of seventy different private, academic and governmen- tal institutions, including five ministries, $A B D I$, the National Agency of Sanitarium Vigilance (ANVISA), the Export Promoting Agency (APEX), the BNDES, the Studies and Projects Funder (FINEP) and the National Institute of Metrology, Standardization and Industrial Quality (INMETRO).

The main discussion panel was promoted in March 2010, with a hundred and twenty professionals of fifty three different public and private institutions. The program included a briefing on the results of the exploratory study, the presentation of the proposals towards the project, followed by a plenary session to analyze the proposals. The second panel was conducted in May 2010 with fifteen professionals of four Ministries (Science and Technology, Industrial and Commercial Development, Environment and Budget and Management Planning), and of three government institutions (FINEP, INMETRO and IBICT - Brazilian Institute of Information in Science and Technology). The third panel was conducted in June 2010 with fifty two professionals of the productive sector, Universities and Research Institutions, ministries and other public institutions.

\section{Planning and pilot project initiation}

After the presentation and debate on the three mentioned panels, some proposals were reconfigured, among which was the proposal of a pilot with only three companies, since there were nine companies that demonstrated interest in participating. This has increased the requirements on the project team, but also allowed the gathering of more rich and representative results. The choice was to enhance the number of "Pilot Companies" (PCs), concentrating efforts on only one of their products, here called "Pilot Product" (PP). The PCs and their PPs and location are presented in Figure I.

A structure to organize the necessary competencies for the development of the project activities was created, containing the following areas and responsibilities:

- $\quad$ Executive Coordination: coordinate, in a systemic way, the several activities of the project, planning and controlling the several actions required.

- $\quad$ Compliance to ABNT IECQ QC 080.000 standard and to WEEE-NPSW: Implement the RoHS-WEEE-NPSW compliance actions in the PCs.

- Ecosystem and Market Demand Management: organize information connected to the E.E. sector; articulate the participation of the several institutions of interest to the project.

- $\quad$ Center for Knowledge Management: collect and organize information; contribute to their diffusion through on-site mechanisms (lectures and courses), off-site mechanisms (web tools) and documents in general (reports and scientific work). 
- Initial and Final Evaluation: evaluate the PCs, aiming to qualify and quantify the generated impact.

The initial evaluation of each PC utilizing the BenchStar methodology was conducted during the May-July $201 \mathrm{I}$ period, involving certain aspects of management (strategy, financing, marketing and personnel), productive processes (quality, production and innovation) and relations with society and the environment (environment, health and security, social responsibility). By the end of the project a new evaluation will be conducted, adopting the same methodology, aiming to evaluate the impacts generated upon each PC.

\section{Innovation towards Sustainability in the PCs}

Although it is impossible to quantify the financial impacts in the PCs resultant of the compliance to environmental requisites of interest to the project, studies and preliminary data (Silveira, Gardesani and Bueno, 2010, Mitsue, 2010, and others) point to a probable enhancement in the costs of components and associated productive processes.

Aiming to solve this situation in such a fashion as to maintain the profit associated with the PP at least at a level close to the current one, ensuring the viability of the TBL principle, this pilot project structures itself around the following hypothesis:

- It is assumed that the final costs of the PP will increase - $\quad$ Considering this probable enhancement in costs, the total profit associated to the PP can be maintained by the following: a. maintaining the current price, however increasing sales in a level that compensates the reduction of unitary profit margins (scenario A); and/or, b. Maintaining the unitary profit margin, however enhancing the product's aggregate value in such a manner that the market can absorb the increase in price (scenario B).

Figure 2 summarizes the scenarios and possible actions aiming to compensate eventual cost enhancements in the final product. Each PC can choose different paths, including the total or partial adoption of the predicted actions in both scenarios.

\section{Management of changes in the PCs}

Having the global purpose of this project in sight, three organizational goals for the PCs were established: I. RoHS, WEEE and NPSW compliance; 2. maintain the competitive

\begin{tabular}{|l|l|l|}
\hline $\begin{array}{l}\text { Pilot Company } \\
(\mathrm{PC})\end{array}$ & Pilot Product (PP) in the Pilot Project & Location \\
\hline A & Electronic Surgical Scalpel & State of SP \\
\hline B & Electronic Surgical Scalpel & State of SP \\
\hline C & Infusion Pump & State of RS \\
\hline D & Ophthalmological Diagnosis & State of SP \\
\hline E & Physiotherapy Product & State of SP \\
\hline F & Incubator & State of SP \\
\hline G & Surgical Table & City of SP \\
\hline H & Physiotherapy Product & State of SP \\
\hline I & Lung Ventilator & State of SP \\
\hline
\end{tabular}

Figure I.The pilot product and the location of the pilot companies

\begin{tabular}{|l|l|l|}
\hline Objective & Scenarios & Possible Actions (examples) \\
\hline $\begin{array}{l}\text { Maintain profit margin } \\
\text { after PP compliance to } \\
\text { RoHS/WEEE/NPSW } \\
\text { requisites. }\end{array}$ & $\begin{array}{l}\text { Maintain product pricing - Lower } \\
\text { unitary profit margin - Enhance } \\
\text { sales }\end{array}$ & $\begin{array}{l}\bullet \text { Emphasize in the media about PP environmental com- } \\
\text { pliance. }\end{array}$ \\
\hline & $\begin{array}{l}\text { Enhance the product's market } \\
\text { price - Maintain unitary profit } \\
\text { margin - maintain sales volume }\end{array}$ & $\begin{array}{l}\text { Explope the "Green Product" niche in PP sales } \\
\text { perception of the product value } \\
\text { Aggregate services to the PP that enhance the custom- } \\
\text { er's perception of the product value }\end{array}$ \\
\hline
\end{tabular}

Figure 2. Summary of Possible Strategies for Product Target (PP)

ISSN: 07 I8-2724. (http://www.jotmi.org)

Journal of Technology Management \& Innovation (c) Universidad Alberto Hurtado, Facultad de Economía y Negocios. 
level of the companies; 3 . support the consolidation of a business strategy based on innovations. The consecution of these three objectives requires a series of changes in each PC. The management of organizational changes implementation can be eased by the identification of the necessary adjustments in the process network of the target organization, as discussed in section 3.4.

The alterations in the processes network of each PC will require the development of three organizational processes, here called PI, P2 and P3, as presented on Figure 3 and commented afterwards.

Planning the development of the $\mathrm{PI}$ process had as one of its main references the work of Ewald (20II) that presents the various existing possibilities of a company to declare compliance to RoHS, such as self-declaration or by trials on individual lots; the option on this project was to implement the ABNT IECQ QC 080.000 standard. Since this standard defines requirements for the management system, its implantation favors the creation of systemic conditions for the maintenance of company sustainability. In addition, these requirements must be applied alongside the ABNT NBR ISO 900 I standard, widely adopted by companies of the E.E. sector and of the electro-electronic sector in general.

The inherent challenges to the maintenance of sustainable conditions with a TBL approach ( $\mathrm{P} 2$ process) require an integrated action plan, with both internal actions and marketing plans. To ease the delivery of these actions, two main sub-processes were defined: I. Integrated management of the marketing mix, aiming towards the viability of the business associated to the PP at the time of its adequacy to environmental requirements; 2 . management of the integration of the several management systems of the PC, creating mechanisms that allow the integrated/systemic management of environmental and business demands, inherent condition to the TBL principle.

The goal associated to the $\mathrm{P} 3$ process is to develop means for the company to be able to maintain its competitiveness over time, through the development of organizational com- petencies that contribute to facing the challenges inherent to competitive and continually evolving markets. As this is as complementary goal to the pilot project, the related changes are not being prioritized in this step.

The two first organizational processes mentioned above (PI and P2) must be unfolded into sub-processes in order to become operational in the conduction of changes in PCs. Figure 4 shows five sub-processes to be developed in the pilot project, and the goals associated to each one of them.

It is desirable to develop the necessary coordination mechanisms between the PCs, their suppliers and the universities and research institutions, in order to facilitate the implementation of all these actions and the attainment of the established goals in the PCs. The intent is to enhance the alignment between the productive activities, the technologic development and technologic services, in such a manner as to make the sustainability of the E.E. sector and their companies viable.

In order to do so, the actions recommended in this project include changes in the PCs and in their supply chain, development of human and technologic competencies in the institutions involved. These actions are organized in three great domains of activities: i. Research, Development and Innovation: related to products, processes and management mechanisms in the institutions involved; ii. Capacitating of collaborators: related to the development of management and technologic competencies that are of interest to the project; iii. Provision of technologic services: Especially those related to hazardous substances and the evaluation of the level of product recyclability.

\section{Final Comments}

The ABIMO Pilot Project presented in this paper has as a central premise that, as far as Brazil is an emerging economy, it is necessary to develop support mechanisms for the country's companies, especially for those small and medium sized and technology intensive, so that they can develop sustainable competitive advantages that allow them to face the multiple challenges existing in national and international markets.

\begin{tabular}{|l|l|}
\hline Target Process to be Developed & Main Related Goal \\
\hline $\begin{array}{l}\text { Production in compliance with RoHS- } \\
\text { WEEE-NPSW (PI Process) }\end{array}$ & $\begin{array}{l}\text { Ensure that the PP is produced in compliance with the } \\
\text { RoHS-WEEE-PNRS }\end{array}$ \\
\hline Manage company sustainability (P2 Process) & $\begin{array}{l}\text { Reach the company's competitive level maintaining good } \\
\text { environmental practices }\end{array}$ \\
\hline $\begin{array}{l}\text { Manage the strategy towards continual } \\
\text { innovation in the company (P3 process) }\end{array}$ & $\begin{array}{l}\text { Maintain company sustainability through time, using strate- } \\
\text { gies based on innovation }\end{array}$ \\
\hline
\end{tabular}

Figure 3. Changes in processes required for achievement of the pilot project objectives

ISSN: 07I 8-2724. (http://www.jotmi.org)

Journal of Technology Management \& Innovation (c) Universidad Alberto Hurtado, Facultad de Economía y Negocios. 
Since companies are highly complex organizational systems in permanent transformation and interaction with their external environment, this proposal was articulated around two fundamentals: a) the search for equilibrium between environmental, economic and social dimensions, as advocated by the TBL sustainability approach; b) integrated management of technological factors, market, organizational and human resources in order to optimize the results obtained. The framework that structures this proposal contains a complex and innovative articulation of a large number of multidimensional variables related to the several agents, aspects and objectives. This allows the integrated management of different factors of interest, both in a specific company and in a broader organizational system, such as a productive chain or even a specific industrial sector (like the E.E. sector).

In order for these articulations produce the desired outcomes, it was necessary to integrate management concepts applicable to ecosystems complex organizational mechanisms to enable the TBL sustainability in companies, and various knowledge about methodologies and intellectual capital management, organizational strategies, innovation management, integrated management systems among others.

The project's emphasis is on the use intellectual capital as a factor of production, since its proper use can provide the necessary means to achieve desirable and sustainable competitive advantages. Another emphasis of this project is the integrated management of the several institutions involved in such a process, since the competitiveness and sustainability of a given economic sector - and therefore every one of their companies - are emerging systemic properties, that strongly rely on the form in which agents that influence the system of interest are articulated amongst themselves.

The project includes some innovative solutions, such as become feasible the TBL approach in companies through the development of strategies based on differentiation, whose implantation occurs through the coordination amongst the necessary innovations in products and processes with the integrated management of marketing mix and integration to the several managerial systems existing in the company. Since the number of companies of the E.E. sector that are compliant to RoHS, WEEE and NPSW is very small, it is also possible to explore the window of opportunities derived from environmentally aware market segments, as a mean to achieve a viable sustainability in the PCs.

The project also includes action mechanisms to foment organizational arrangements towards innovation, based on the triple helix principle (government, academy and companies), aiming to create synergies between the participating companies, their suppliers and the R\&D institutions involved, and at the same time preserving the individual liberties in which each PC can make their own decisions, based on their strategic priorities.

Therefore, the proposal presented here has several features which make it unique, being structured to simultaneously achieve multiple and relevant objectives, such as:

- Seek the environmental compliance of technology intensive sectors in accordance to the TBL principle.

\begin{tabular}{|c|c|c|c|}
\hline Main Processes & Associated Objective & & \\
\hline & Designations & & \\
\hline \multirow[t]{3}{*}{$\mathrm{P} 1$} & P1.1. & Develop capacitated suppliers & $\begin{array}{l}\text { Develop a supply chain able to supply RoHS } \\
\text { compliant items in an economic feasible } \\
\text { way to the PC. }\end{array}$ \\
\hline & $\mathrm{P} 1.2$ & $\begin{array}{l}\text { Manage the materials free of } \\
\text { hazardous substances. }\end{array}$ & $\begin{array}{l}\text { Guarantee the compliance of materials used } \\
\text { in the PP }\end{array}$ \\
\hline & $\mathrm{P} 1.3$ & $\begin{array}{l}\text { Control the production with } \\
\text { materials free of hazardous } \\
\text { substances. }\end{array}$ & $\begin{array}{l}\text { Develop and maintain compliant production } \\
\text { and supply processes throughout time }\end{array}$ \\
\hline \multirow[t]{2}{*}{$\mathrm{P} 2$} & P2.1. & $\begin{array}{l}\text { Manage the marketing mix of } \\
\text { PP which facilitates the com- } \\
\text { pany's sustainability }\end{array}$ & $\begin{array}{l}\text { Provide the PP in compliance with the } \\
\text { RoHS-WEEE-PNRS, but keeping the net } \\
\text { profits arising from its sale. }\end{array}$ \\
\hline & $\mathrm{P} 2.2$. & $\begin{array}{l}\text { Integrated management of the } \\
\text { PC's managerial systems }\end{array}$ & $\begin{array}{l}\text { Implement a integrated management system } \\
\text { that offers means to integrate processes and } \\
\text { environmental requirements to further regu- } \\
\text { lations and business demands }\end{array}$ \\
\hline
\end{tabular}

Figure 4. Main Processes for the Consecution of the Project's Objectives

ISSN: 07 I8-2724. (http://www.jotmi.org)

Journal of Technology Management \& Innovation (c) Universidad Alberto Hurtado, Facultad de Economía y Negocios. 
- Enable conditions so that small and middle sized Brazilian companies can comply with the various environmental requirements maintaining their competitiveness.

- Integration of professionals from several knowledge areas, articulating a set of complementary competencies.

- Organizational ecosystem management focusing on the companies, coordinating several institutions based on the triple helix conception.

\section{Acknowledgments}

The author thanks to the efforts of various professionals and institutions that contributed to the viability of this project. We highlight the contributions made by MCTI (Ministry of Science, Technology and Innovation), in the person of Dr. Henrique Miguel, and CTI / MCTI (Center for Information Technology Renato Archer), who hosts the majority of the members of the executive board of the project.

\section{Notes}

The expression "organizational system" can be used to designate an individual company, a group of companies, an economic sector, or groups of institutions in cooperative arrangements (like organizational networks and National Institutes of Science and Technology).

The mentioned authors emphasize the importance of "human capital" in the development of intellectual capital for three reasons: a) their potential to enhance structural capital; b) their capacity to internalize in the organization the results of the relational capital, potentiating the out coming results; c) their capacity to generate new knowledge.

The BenchStar methodology was created by the Euvaldo Lodi Institute (IEL) in Brazil to support the development of micro, small and medium sized companies belonging to a group of common interest, like the PCs in this project. Being a benchmarking tool, its main purpose is to measure competitiveness evaluating the position each company has in the group.

The goal of the ABNT IECQ QC 080.000 standard is to specify requirements for the development of identification, control and qualification processes and to report the quantities of HS "Hazardous Substances" in products manufactured or provided by them.

\section{References}

ABDI - Agência Brasileira de Desenvolvimento Industrial (2008). Estudo prospectivo: Equipamentos médicos, hospitalares e odontológicos. Brasília.

ABINEE - Associação Brasileira da Indústria elétrica e eletrônica (2009). A indústria elétrica e eletrônica em 2020. Uma estratégia de desenvolvimento. São Paulo.

AKTOUF, O. (1996). A Administração entre a tradição e a renovação. São Paulo:Atlas.

DAY, G.S.; Rebstein, D.J. (2004).Wharton on Dynamic Competitive Strategy. New York: John Wiley and Sons.

EDVINSSON, L., Malone, M.S (1997). Intellectual Capital: Realizing Your Company's True Value by Finding Its Hidden Brainpower. New York: Harper Collins,

ELKINGTON, J. (1998). Cannibals with forks. New Society Publische.

EWALD, M.R. (20II). Implantação dos requisitos ABNT IECQ QC 080.000. Documento interno. Campinas: Centro de Tecnologia da Informação Renato Archer.

GONÇALVES, J.E.L. (2000). As empresas são grandes coleções de processos. Revista de Administração de Empresas. São Paulo: FGV, v.40, n. I, Jan./Mar., 6-19.

GOUVEIA, F. (2004) O papel das subsidiárias brasileiras na nova configuração das corporações multinacionais: Um estudo com base na indústria eletrônica. Dissertação (Mestrado) - Instituto de Economia, Universidade Estadual de Campinas, Campinas.

KAST, F.E., Rosenzweig,J.E. (1985). Organization and management: a systems approach. Tokyo: McGraw-Hill.

KIRBY, K.E. (I99|). “Organizational change: The systems approach" in Stahl e Bounds (ed.). Competing globally through customer value:The management of Strategic suprasystems, Westport: Quorum Books.

KOTLER, P;Armstrong, P. (2004). Marketing. Madrid: Prentice Hall.

MITSUE, H. (20I0). Custos da Logística Reversa de PósConsumo: Um estudo de caso dos aparelhos e das baterias de telefonia celular descartados pelos consumidores. Disponível em www.teses.usp.br/teses/disponiveis//2//2/36/ tde.../MitsueHori.pdf. Accessed March 12, 2013.

ISSN: 07I 8-2724. (http://www.jotmi.org) 
MONTGOMERY, C.A.; Porter, M. E. (199I). Strategy: Seeking and secure competitive advantage. Massachusetts: Harvard Business Press.

MORGAN, G (2006). Images of organization. California: Sage Publications.

OLIVEIRA, L.H., Silveira, M. A. (2009). Caracterização e análise da cadeia produtiva de PCIs. In: SIMPOI 2009: "XII Simpósio de Administração da Produção, Logística e Operações Internacionais", 2009, São Paulo. Anais do SIMPOI 2009. São Paulo: Editora da FGV. v.I. p.I - 15

PIERONI, J. P.; Reis, C. e Souza, J. O. B. (2010) A indústria de equipamentos e materiais médicos, hospitalares e odontológicos: uma proposta de atuação do BNDES. Complexo Industrial da Saúde. BNDES Setorial 31: I85-226, Rio de Janeiro.

PORTER, M.E (1998). Competitive strategy: techniques for analysing industries and competitors. New York: The Free Press

REYDON, B.P.; Cavini, R.A.; Escobar, H.E.H.; Faria, H.M. (2007). A competitividade verde enquanto estratégia empresarial resolve o problema ambiental. Documento interno. Campinas: Instituto de Economia - Unicamp

SCHODERBEK, C.G.; Schoderbek, P.P.; Kefalas, A.G. (1980). Management systems: Conceptual considerations. Dallas: Business Publications.

SILVEIRA, M. A. (2004). Gestão estratégica da inovação em organizações: Proposta de um modelo com enfoque sistêmico In: XXIII Simpósio de Gestão da Inovação Tecnológica, 2004, Curitiba. XXIII Simpósio de gestão da Inovação Tecnológica, p.4279 - 4294

(1999) Modelo para sistemas da qualidade como base da estratégia competitiva. Universidade Estadual de Campinas. FEM (Tese Doutorado).

SILVEIRA, M. A., Gardesani, R., Bueno, A.K.S. (20I0) Supply and Reverse Supply Chains in the Brazilian Electro-Medical Equipment Industry: A Multiple Case Study for Compliance with WEEE and RoHS Directives In:APMS-20I0 International Conference, Como - Itália. APMS-20I0.

SVEIBY, K.E. (1997). The new organizational wealth: Managing and measuring knowledge-based assets. San Francisco: Berrett-Koehler Publishers.

TIDD, J.; Bessant, J.; Pavitt, K. (1997). Managing innovation: Integrating technological, market and organizational change. John Wiley \& Sons.

ISSN: 07I 8-2724. (http://www.jotmi.org) Journal of Technology Management \& Innovation (c) Universidad Alberto Hurtado, Facultad de Economía y Negocios. 